\title{
Efficacy of North American Crotalid Antivenom Against the African Viper Bitis gabonica (Gaboon Viper)
}

\author{
William J. Meggs • Christopher N. Wiley • \\ Kori L. Brewer • Jason B. Hack
}

Published online: 12 March 2010

(C) American College of Medical Toxicology 2010

\begin{abstract}
Envenomations by exotic snakes occur from zoological collections and private individual collectors. Antivenoms to these snakes may not be readily available. The objective of this study is to determine the efficacy of North American crotalid antivenin in treating mice envenomated with venom of the African viper Bitis gabonica (Gaboon viper). The subjects of the study were Swiss Webster mice weighing approximately $30 \mathrm{~g}$. The study was conducted in the University research laboratory. B. gabonica venom was obtained from Venom Supplies Pty Ltd (Tanunda, South Australia) and reconstituted in sterile water. North American Crotalid Fab2 antivenin (Anavyp ${ }^{\circledR}$, Instituto Bioclon, Mexico) was donated by the manufacturer. The experimental groups were: Group I received two times an intraperitoneal $\mathrm{LD}_{50}$ dose of venom, $2.58 \mathrm{mg} / \mathrm{kg}$. Group II received the same dose after incubation for $1 \mathrm{~h}$ with $10 \mathrm{mg}$ of antivenin. Time to onset of toxicity defined as respiratory rate $<10 / \mathrm{min}$ or absence of response to prodding. $t$ test and Chi square with $p<0.05$ considered significant. Time to onset of toxicity was $7.040 \pm 4.334 \mathrm{~h}$ in group I, and $20.665 \pm 2.074$ in group II $(p=0.0064,95 \%$ confidence interval of difference of means -22.694 to -4.556). Antivenin was efficacious to statistical significance at $4,8,12$, and $16 \mathrm{~h}$ ( $p$ values of $0.062,0.0067$, 0.0067 , and 0.0253 , respectively). Improvement at 20 and $24 \mathrm{~h}$ ( $p$ values of 0.0673 and 0.0673 , respectively) did not achieve statistical significance. North American Crotalid antivenin (Anavyp ${ }^{\circledR}$, Instituto Bioclon, Mexico) demonstrated efficacy in increasing time to onset of distress in
\end{abstract}

\footnotetext{
W. J. Meggs $(\bowtie) \cdot$ C. N. Wiley $\cdot$ K. L. Brewer $\cdot$ J. B. Hack Department of Emergency Medicine, Brody School of Medicine at East Carolina University, 600 Moye Boulevard, Room 3ED311, Greenville, NC 27858, USA

e-mail: meggsw@ecu.edu
}

mice poisoned with B. gabonica (Gaboon viper) venom. Based on this result, treatment of humans envenomated with $B$. gabonica with North American Croatlid antivenin could be considered for severe envenomations if specific B. gabonica antivenin is unavailable.

Keywords Snakebite $\cdot$ Antivenom $\cdot$ Gaboon viper

\section{Introduction}

Envenomation by exotic or non-native snakes is a worldwide problem [1-5]. In the USA, the number of exotic poisonous snake bites reported to the American Association of Poison Control Centers Toxic Exposure Surveillance system over the last 5 years ranged from 96 to 131 per year [6-10]. Species-specific antivenom, the definitive treatment of poisonous snake bites, may not be readily available for exotic species. When antivenom is available, it is often whole antibody serum derived from horse serum with a greater potential for anaphylactic reactions and serum sickness than the Fab products that are available for native species.

Mouse lethality models have been used to establish the efficacy of antivenoms between native and non-native snakes. Wisniewski and collaborators employed this model to demonstrate that Australian tiger snake (Notechis scutatus) and Mexican coral snake (Micrurus species) antivenoms are efficacious against a United States coral snake (Micrurus fulvius fulvius) [11]. Richardson and his collaborators demonstrated that North American coral snake antivenom is efficacious against the venom of nonnative elapids such as cobras [12], and that North American crotalid antivenom is efficacious in treating South American vipers [13]. The efficacy of North American crotalid 
antivenom against venom of vipers native to Africa has never been studied.

This study of the efficacy of a North American crotalid antivenom (Anavyp ${ }^{\circledR}$, Instituto Bioclon, Mexico) against the Gaboon viper (Bitis gabonica) native to Africa was motivated by difficulties treating a Gaboon viper envenomation at our institution. Specific horse serum antivenin was obtained with difficulty and delays and resulted in anaphylactic reaction. Though exotic snakebites are rare, they do occur as illustrated by five other recent cases of Gaboon viper envenomations in North American [14].

The objective of this study was to use a mouse lethality model [11-13] to determine the efficacy of a North American crotalid antivenom (Anavyp ${ }^{\circledR}$, Instituto Bioclon, Mexico) in treating mice given the venom of the African viper $B$. gabonica (Gaboon viper). It can be hypothesized that a North American crotalid $(\mathrm{Fab})_{2}$ antivenom would prolong the survival time of mice given the venom of the African viper B. gabonica.

\section{Material and Methods}

Materials Swiss Webster mice weighing approximately $30 \mathrm{~g}$ were used (Jackson Laboratories, Bar Harbor, Maine). They were housed in a standard mouse cage and fed standard mouse feed ad libitum. Gaboon viper venom was obtained from Venom Supplies Pty Ltd (Tanuda, South Australia). (Fab) $)_{2}$ antivenom to North American rattlesnakes was donated by the manufacturer (Laboratorios Silanes S.A. de C.V., Mexico)

Study Design A randomized, placebo-controlled trial of the efficacy of a North American crotalid antivenom (Anavyp $^{\circledR}$, Instituto Bioclon, Mexico) in mice given Gaboon viper venom was performed. Mice were used because they have been previously used to study the cross-reactivity of species-nonspecific antivenom [11-13].

The study mice were divided into two groups. The control group received B. gabonica venom and 0.9\% normal saline solution. The treatment group received $B$. gabonica venom and $\mathrm{Fab}_{2}$. The control group consisted of five animals and the experimental group consisted of ten animals. All animals received the same injection volume and venom concentration.

Mice were given analgesia with a single dose of buprenorphine $(0.01 \mathrm{mg} / \mathrm{kg})$ by subcutaneous injection prior to administration of venom, using a No. 27 needle, $30 \mathrm{~min}$ prior to venom injection. The dose of venom used was two times the published $\mathrm{LD}_{50}$ in mice $(1.58 \mathrm{mg} / \mathrm{kg})$ [15]. Antivenom was received as a lyophilized powder that was reconstituted in $10-\mathrm{mL}$ sterile water per vial. Mice in the treatment group received a venom-antivenom solution that was pre-mixed in a $3-\mathrm{mL}$ syringe and incubated at $25^{\circ} \mathrm{C}$ for $1 \mathrm{~h}$ before intraperitoneal injection. The premixed syringes were diluted to a total volume of $1 \mathrm{~mL}$ to provide a uniform volume for intraperitoneal injection. All animals were weighed to determine the dose of venom to be administered. Normal saline solution was used for venom and antivenom dilutions.

Outcome Measures Primary outcome measures used were signs of distress and time to onset of distress for a 24-h period following the injections. Animals that showed signs of distress were euthanized by $\mathrm{CO}_{2}$ inhalation. Distress was defined as respiratory rate less than ten breaths per minute or lack of response to a gentle tap on the back. Mice were observed continuously for the first $8 \mathrm{~h}$. They were observed at 2 -h intervals for the second $8 \mathrm{~h}$. They were observed at 4-h intervals for the last $8 \mathrm{~h}$ of the study. At the conclusion of the 24-h study period, animals were euthanized by $\mathrm{CO}_{2}$ inhalation. An independent observer, blinded to the group assignments, observed the animals and determined onset of distress.

Statistical Analysis $t$ test and Chi square with $p<0.05$ considered significant.

Results Time to onset of distress or survival to $24 \mathrm{~h}$ was $7.040 \pm 4.334 \mathrm{~h}$ in the control group and $20.67 \pm 2.07 \mathrm{~h}$ in the treatment group ( $p=0.0064,95 \%$ confidence interval of difference of means -22.69 to -4.56 ; Fig. 1). Seven of ten mice $(70 \%)$ in the treatment group survived to $24 \mathrm{~h}$ of while only one of five mice $(20 \%)$ in the control group survived the full $24 \mathrm{~h}$. Antivenom improved survival without distress at $4,8,12$, and $16 \mathrm{~h}$ ( $p$ values of 0.0062 , $0.0067,0.0067$, and 0.0253 , respectively). Survival was improved at 20 and $24 \mathrm{~h}$ ( $p$ values of 0.0673 and 0.0673 , respectively) but statistical significance was not obtained.

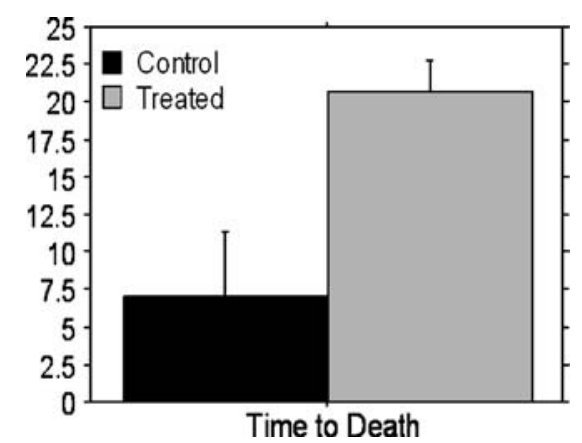

Fig. 1 Time to death in hours of the control vs. treated group. The mean time to death for the control group was significantly shorter than that of the treated group $(7.04 \pm 4.3 \mathrm{~h}$ versus $20.67 \pm 2.1 \mathrm{~h} ; p=0.006)$ 


\section{Discussion}

This study evaluated the efficacy of North American crotalid $(\mathrm{Fab})_{2}$ antivenom (Anavyp ${ }^{\circledR}$, Instituto Bioclon, Mexico) in treating mice injected with venom of the African viper B. gabonica (Gaboon viper). The North American antivenom was efficacious in this model. Other investigators have found that Australian tiger snake $(N$. scutatus) and Mexican coral snake (Micrurus species) antivenoms have efficacy against a United States coral snake (M. fulvius fulvius) [11]. A North American crotalid antivenom is efficacious in treating two South American crotaline snakes: Crotalus durissus terrificus (tropical rattlesnake) and Bothrops atrox (fer-de-lance) [12]. A North American coral snake antivenom is efficacious in treating two exotic elapid envenomations: Naja naja (Indian cobra) and Dendroaspis polylepsis (black mamba) [13].

While specific antivenoms are available in other countries to their native species, they are not readily available to emergency physicians in the USA. Zoos and other facilities that maintain collections of poisonous snakes often maintain stocks of antivenom against the venoms of snakes in their collections. Poison control centers maintain an Antivenom Index to assist in locating species-specific antivenom. If a patient is seriously ill after a non-native viper bite and specific antivenom is not available, using a native antivenom may be reasonable in light of these studies.

One of the limitations of this experiment is that the antivenom and the venom were mixed together prior to the injection into the mice. This does not accurately re-create what occurs in human snake envenomations in which the antivenom and venom enter the body separately and are mixed in vivo rather than in vitro. Another limitation in this study was that one of the mice in the control group survived the full $24 \mathrm{~h}$ of the experiment, while three of ten in the treatment group did not. That there were deaths in the treatment group most likely indicates an inadequate dose of antivenom. If a second or higher dose of antivenom were given, survival in the treatment group may have improved.

A dose-response curve was not performed for the venom used in the interest of limiting the number of animals used and not reproducing published results. A protein control was not used to determine that efficacy was from specificity of the antivenom rather than nonspecific binding of venom to protein, but this has been established for other venoms and antivenoms [11] and we have no reason to believe that nonspecific protein binding was responsible for the effect seen. In spite of these limitations, the study found a statistically significant improvement in survival with treatment.

This work extends earlier investigations demonstrating efficacy between venoms and antivenoms with similar toxicity $[11-13]$ to an African viper. A clinician treating a severe poisonous snake bite can consider giving available elapid or viper antivenom while trying to find a speciesspecific antivenom. If species-specific antivenom is available but an intact horse serum antibody that is more likely to produce anaphylactic shock or serum sickness is not tolerated, a clinician could consider initiating treatment with $\mathrm{Fab}$ or $\mathrm{Fab}_{2}$ fragments.

\section{References}

1. de Haro L, Pommier P (2003) Envenomation: a real risk of keeping exotic house pets. Vet Hum Toxicol 4:214-216

2. Reid HA (1978) Bites by foreign venomous snakes in Britain. BMJ 1:1598-1600

3. Schneemann M, Cathomas R, Laidlow ST (2004) El Nahas AM, Theakston RD, Warrell DA. Life-threatening envenoming by the Saharan horned viper (Cerastes cerastes) causing micro-angiopathic haemolysis, coagulopathy and acute renal failure: clinical cases and review. Q J Med 97:717-727

4. Warrell DA (2005) Treatment of bites by adders and exotic venomous snakes. BMJ 331:1244-1237

5. Minton SA (1996) Bites by non-native venomous snakes in the United States. Wilderness Environ Med 7:297-303

6. Lin WS, Hwang MS, Chung HT, Chu JJ, Lai MW, Yang JS, Huang SC, Huang JL, Su WJ (2006) 2005 Annual Report of the American Association of Poison Control Centers' national poisoning and exposure database. Clin Toxicol 44:803-932

7. Watson WA, Litovitz TL, Rodgers GC Jr, Klein-Schwartz W, Reid N, Youniss J, Flanagan A, Wruk KM (2005) 2004 Annual report of the American Association of Poison Control Centers Toxic Exposure Surveillance System. Am J Emerg Med 23:589-666

8. Watson WA, Litovitz TL, Klein-Schwartz W, Rodgers GC Jr, Youniss J, Reid N, Rouse WG, Rembert RS, Borys D (2004) 2003 annual report of the American Association of Poison Control Centers Toxic Exposure Surveillance System. Am J Emerg Med 22:335-404

9. Watson WA, Litovitz TL, Rodgers GC Jr, Klein-Schwartz W, Youniss J, Rose SR, Borys D, May ME (2003) 2002 annual report of the American Association of Poison Control Centers Toxic Exposure Surveillance System. Am J Emerg Med 21:353-421

10. Litovitz TL, Klein-Schwartz W, Rodgers GC Jr, Cobaugh DJ, Youniss J, Omslaer JC, May ME, Woolf AD, Benson BE (2002) 2001 Annual report of the American Association of Poison Control Centers Toxic Exposure Surveillance System. Am J Emerg Med 20:391-452

11. Wisniewski MS, Hill RE, Havey JM, Bogdan GM, Dart RC (2003) Australian tiger snake (Notechis scutatus) and Mexican coral snake antivenom prevent death from United States coral snake (Micrurus fulvius vulvius) venom in a mouse model. Clin Tox 41:7-10

12. Richardson WH 3rd, Tanen DA, Tong TC, Betten DP, Carstairs SD, Williams SR, Cantrell FL, Clark RF (2006) North American coral snake antivenin for the neutralization of non-native elapid venoms in a murine model. Acad Emerg Med 13:121-126

13. Richardson WH 3rd, Tanen DA, Tong TC, Betten DP, Carstairs SD, Williams SR, Cantrell FL, Clark RF (2005) Crotalidae polyvalent immune Fab (ovine) antivenom is effective in the neutralization of South American viperidae venoms in a murine model. Ann Emerg Med 45:595-602

14. Marsh N, DeRoos F, Touger M (2007) Gaboon viper (Bitis gabonica) envenomation resulting from captive specimens-a review of five cases. Clin Toxicol 45:60-64

15. Brown JH. Toxicology and Pharmacology of Venoms from Poisonous Snakes. Springfield, Illinois, 1977: Charles C. Thomas. 